
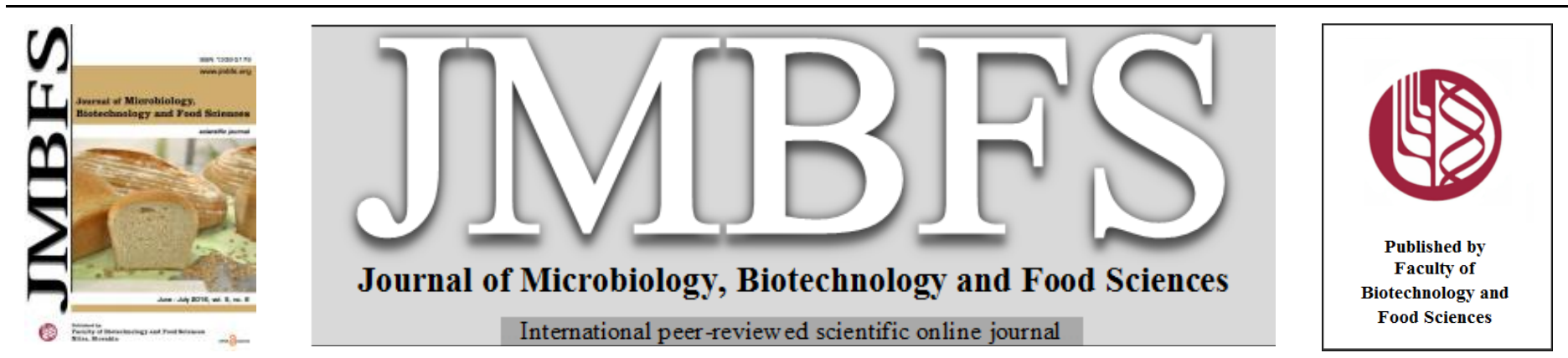

\title{
ENHANCED PRODUCTION OF POLYHYDROXYBUTYRATE (PHB) FROM AGRO-INDUSTRIAL WASTES; FED- BATCH CULTIVATION AND STATISTICAL MEDIA OPTIMIZATION
}

\author{
Mahmoud M. Berekaa ${ }^{l}$ and Adil M. Al Issa ${ }^{2}$ \\ Address(es): Dr. Mahmoud Berekaa, \\ ${ }^{1}$ University of Dammam, College of Applied Medical Sciences, Environmental Health Department, Dammam 31441, Saudi Arabia. +966-0133331304. \\ ${ }^{2}$ University of Dammam, College of Education, Biology Department, Dammam 31451, Saudi Arabia.
}

*Corresponding author: mberekaa@uod.edu.sa

doi: 10.15414/jmbfs.2016.5.6.606-611

\section{ARTICLE INFO}

Received 20. 9. 2014

Revised 7. 2. 2016

Accepted 1.3. 2016

Published 1. 6. 2016

Regular article

OPEN $\partial_{\text {ACCESS }}$

\begin{abstract}
Bacillus megaterium SW1-2 showed enhanced growth and polyhydroxybutyrate (PHB) production during cultivation on date palm syrup (DEPS) or sugar cane molasses. FT-IR and NMR spectroscopic analyses of the polymer accumulated during growth on DEPS revealed specific absorption peaks characteristic for PHB. $1.65 \mathrm{~g} / \mathrm{L}$ of PHB $(56.9 \% \mathrm{CDW})$ was produced during growth on medium supplemented with $2 \mathrm{~g} / \mathrm{L}$ of DEPS. Approximately, 36.1\% CDW of PHB were recorded during growth on sugar cane molasses. Six runs of different fed-batch cultivation strategies were tested, the optimal run showed approximately 6.87-fold increase. Modified E2 medium was prefered recording 10.11 and $11.34 \mathrm{~g} / \mathrm{L}$ of total PHB produced for runs 1 and 2, at the end of $96 \mathrm{~h}$ incubation period, respectively. Decrease in PHB was recorded during growth on complex medium (run 3 and run 4). In another independent optimization strategy, ten variables were concurrently examined for their significance on PHB production by Plackett-Burman statistical design for the first time. Among variables, DEPS-II and inoculum concentration followed by $\mathrm{KH}_{2} \mathrm{PO}_{4}$ and $\left(\mathrm{NH}_{4}\right)_{2} \mathrm{SO}_{4}$ were found to be the most significant variables encourage PHB production. Indeed, DEPS-II or Fresh syrup is more significant than commercial syrup DEPS-I ( $p$ value $=0.05)$. RPM, incubation period have highly negative effect on PHB production. Role of ago-industrial wastes, especially DEPS, in enhancement of PHB production was closely discussed.
\end{abstract}

Keywords: Date syrup or DEPS, Polyhydroxybutyrate (PHB), Bacillus megaterium, Plackett-Burman design, fed-batch cultivation, optimization

\section{INTRODUCTION}

Among the most commonly known biopolymers, bacteria polyhydroxyalkanoates (PHAs) polyesters gain more interest. It is synthesized and intracellular accumulated as storage materials to be used as energy source during unbalanced growth (Anderson and Dawes, 1990; Steinbuchel 2001; Du and Yu, 2002; Ojumu et al., 2004). PHB production by microorganisms attracted attention of many scientists due to close resemblance to synthetic petroleum-based plastics such as polypropylene (Mokhtari-Hosseini et al., 2009), biodegradability and biocompatiblility (Madison and Huisman, 1999; Ojumu et al., 2004; Khanna and Srivastava, 2005). Several applications in medicine, veterinary practice, tissue engineering materials, food packaging and agriculture have been reported (van der Walle et al., 2001; Zinn et al., 2001; Luengo et al., 2003; Chen and Wu, 2005; Bucci et al., 2005; Urtuvia et al. 2014). Many bacilli have been reported to accumulate PHA and co-polymers of $3 \mathrm{HB}$ during growth on different substrates (Belma et al., 2002; Tajima et al. 2003; Valappil et al., 2007; Adwitiya et al., 2009; Reddy et al., 2009). In spite the privilege of microbial PHAs production compared with petroleum-derived plastics, costs of the feedstock are the main limiting factor for their mass production (Ojumu et al., 2004; Nikel et al., 2005). Economically, the use of agro-industrial wastes, improved fermentation strategies and downstream processes have positive contribution on the overall biopolymer production costs (Liu et al. 1998; Tamer et al. 1998; Kim, 2000; Halami, 2008).

Recently, scientists have been exploring different cultivation strategies involving inexpensive, renewable carbon substrates in order to reduce production cost and obtain high productivity (Ojumu, 2004). Many carbon sources derived from wastes like whey, cane molasses, sugar beet molasses and date syrup can be used in production (Beaulieu et al., 1995; Lee et al., 1997; Liu et al., 1998; Omar et al., 2001; Khanafari et al., 2006; Albuquerque et al., 2007; Hamieh et al., 2013). Nowadays, PHB proved to be produced from relatively cheaper substrates such as methanol (Kim et al., 2003; Mokhtari-Hosseini et al., 2009), carbon dioxide (Ishizaki et al., 2001), and several agro-industrial by-product such as rice bran, pulp, paper and cardboard industry, whey, dairy wastes, sea water and municipal wastes (Law et al., 2001; Nikel et al., 2005; Nath et al., 2008; Santimano et al., 2009; Pandian et al., 2010; Bhuwal et al., 2013; Hamieh et al., 2013; Singh et al., 2013; Watanabe et al., 2014). Furthermore, fed-batch cultivation in chemically defined medium for optimization of PHB production has been applied (Wang and Lee., 1997; Liu et al., 1998). Investigations have also focused on reducing the total cost of PHB through optimizing fermentation processes. Recently, application of statistical methods has gained a lot of impetus for medium optimization and understanding the interactions among various physiochemical parameters involved in biopolymer production (Khanna and Srivastava, 2005; Nikel et al., 2005; Sharma et al., 2007; Mokhtari-Hosseini et al., 2009; Pandian et al., 2010; Berekaa and Al Thawadi., 2012; Hamieh et al., 2013).

The main objective of this study was to investigate the possible production of PHB from several agro-industrial wastes mainly; date palm syrup (DEPS) and sugar cane molasses. Produced polymer was identified by chemical characterization using FT-IR, $\mathrm{C}^{13} \mathrm{NMR}$ and $\mathrm{H}^{1} \mathrm{NMR}$ spectroscopy. Furthermore, optimization of PHB production by application of six different fed-batch cultivation strategies was closely investigated. Special emphasis was given to the application of statistical experimental design (Plackett-Burman) for optimization of PHB production from DEPS for the first time.

\section{MATERIAL AND METHODS}

\section{Microorganism}

Group of bacilli previously isolated, maintained and screened for PHB production (Berekaa and Al Thawadi, 2012; Berekaa, 2012), were tested for PHB production from agro-industrial wastes namely; date syrup (DEPS) and sugar cane molasses. The potent PHB producing bacterial strain Bacillus megaterium SW1-2 used in this study was identified by 16S DNA gene analysis as previously reported (Berekaa and Al Thawadi, 2012).

\section{Growth and production conditions}

The bacterium was grown in $50 \mathrm{~mL}$ aliquot of nutrient broth dispensed in $250 \mathrm{~mL}$ Erlenmeyer flask and incubated at $37^{\circ} \mathrm{C}$ for $24 \mathrm{~h}$ or $48 \mathrm{~h}$ at $(150 \mathrm{rpm}) .1 .5 \%$ inoculums of the overnight culture was used to inoculate modified E2 medium of 
the following composition (g/L): ammonium sulfate; 2.5, $\mathrm{KH}_{2} \mathrm{PO}_{4} ; 1.5$, $\mathrm{Na}_{2} \mathrm{HPO}_{4} ; 3.5, \mathrm{MgSO}_{4} .7 \mathrm{H}_{2} \mathrm{O} ; 0.2$, traces of yeast extract and $1 \mathrm{~mL}$ of trace element solution $\left(\mathrm{FeSO}_{4} \cdot 4 \mathrm{H}_{2} \mathrm{O}, \mathrm{CaCl}_{2} \cdot 2 \mathrm{H}_{2} \mathrm{O}, \mathrm{MnSO}_{4} \cdot 4 \mathrm{H}_{2} \mathrm{O}, \mathrm{ZnCl}_{2} 1 \mathrm{mM}\right.$ each) at $37^{\circ} \mathrm{C}$. To test the possible production of $\mathrm{PHB}$, date palm syrup (DEPS) or sugar cane molasses was used as a sole carbon source at different concentrations. Two types of date syrup (DEPS) were used in this study, the commercial (DEPS-I) composed mainly of (per $100 \mathrm{~g}$ ); carbohydrates $55 \mathrm{~g}$ (mainly sucrose), vitamin B complex $0.57 \mathrm{mg}$, calcium $685 \mathrm{mg}$, phosphate $75 \mathrm{mg}$, iron $16 \mathrm{mg}$ and magnesium $258 \mathrm{mg}$ ) and Freshly prepared date palm syrup (DEPS-II) as following; $500 \mathrm{~g}$ of date palm (Khalas from Kaseem province) were placed in $1.5 \mathrm{~L}$ dist. water and boiled for $90 \mathrm{~min}$ with mixing. At the end of incubation period the extract was filtered in cloth for 3-4 times. Subsequently, the extract kept in oven at $60^{\circ} \mathrm{C}$ till net volume of $200 \mathrm{~mL}$. Finally, the fresh date syrup was kept in refrigerator till use. Sugar cane molasses used in this study were obtained from an industria sugar manufacturing plant, Egypt. Sugar content of molasses was $76 \%$ (w/v), and composed mainly of sucrose $(62 \%)$, and fructose $(38 \%)$. At the end of incubation period, PHB was determined and the cell dry weight was estimated.

\section{Fed-batch cultivation and PHB production strategies}

For optimization of PHB production from date syrup (DEPS), fed-batch cultivation was applied. During fed-batch cultivation, two different feeding strategies were applied. The first pulsed feeding of DEPS-I was carried out after 24 and $60 \mathrm{~h}$ time intervals, while the second was performed after 48 and $84 \mathrm{~h}$, respectively, with final concentration of $15 \mathrm{~g} / \mathrm{L}$. Furthermore, three basal media were tested in this study namely; modified E2 medium, nutrient broth medium and a mixture of nutrient broth and modified E2 medium $(50 \%$ w/w each) with the sum of six different fed-batch cultivation strategies (run 1 to run 6). In each experiment, sample was taken during different time intervals, PHB was determined and the cell dry weight was estimated.

\section{Extraction of PHB from the isolate}

PHB was extracted from the cell masses by using modified hypochlorite method as previously described (Rawte and Mavinkurve, 2002; Berekaa and Al Thawadi, 2012).

\section{Analytical procedures}

\section{Cell dry weight}

After centrifugation of the culture medium, supernatant was discarded and cell pellet was washed with distilled water. The washed pellet was resuspended in 1 $\mathrm{mL}$ distilled water, transferred to pre weighed boats and dried to constant weight at $60^{\circ} \mathrm{C}$

\section{Chemical analysis of polymer}

\section{Characterization of PHB by FT-IR}

The presence and characterization of PHB in dry cell matter was confirmed by Fourier Transform Infrared Spectroscopy (FT-IR) (Hong et al., 1999). Dry PHB polymer from $B$. megaterium $\mathrm{SW1-2}$ was used to prepare $\mathrm{KBr}$ discs. Spectra between 400 and $4000 \mathrm{~cm}^{-1}$ were recorded using Nicolet 6700 FTIR spectrometer from the Nicolet Instrument Corporation, USA.

\section{Characterization of PHB by $C^{13} N M R$ and $H^{1}$ NMR analysis}

Extracted PHB biopolymer from B. megaterium SW1-2 was characterized by spectroscopic analysis. $\mathrm{H}^{1} \mathrm{NMR}$ spectrum was recorded on a JEOL JNM-LA 500 $\mathrm{MHz}$ spectrometer at $30^{\circ} \mathrm{C}$ in $\mathrm{CDCl}_{3}$ as solvent. While, $\mathrm{C}^{13} \mathrm{NMR}$ spectral experiments were performed at $125.65 \mathrm{MHz}$ with the following acquisition parameters: $32 \mathrm{k}$ data point, $0.967 \mathrm{~s}$ acquisition time, recycle delay $1 \mathrm{~s}$ and contact time $4.50 \mathrm{~ms}$.

\section{Fractional factorial design}

\section{Plackett-Burman experimental design}

Screening design namely; Plackett-Burman experimental design was applied to investigate the significance of various medium factors on PHB production (Plackett and Burman, 1946). 10 chemical and environmental independent variables were examined in two levels: -1 for low and +1 for high level based on Plackett-Burman design (Table 1). According to the matrix shown in Table 2, the independent variables were screened in 14 combinations. The main effect of each variable is the difference between average of measurements at high setting $(+1)$ and average of measurements observed at low setting $(-1)$ of that factor. PlackettBurman experimental design was based on the first order model (Equation 1):

\section{$\mathrm{Y}=\beta 0+\Sigma \beta \mathrm{iXi}(1)$}

Where, $\mathrm{Y}$ is the predicted response, $\beta 0$ and $\beta \mathrm{i}$ are constant coefficients, and $\mathrm{Xi}$ is the coded independent variables estimates or factors. The quality of fit of the polynomial model equation was expressed by the coefficient of determination $\mathrm{R}^{2}$.

Table 1 Variables and their settings employed in Plackett-Burman design for optimization of PHB production by Bacillus megaterium SW1-2 during growth on date syrup or DEPS.

\begin{tabular}{lcc}
\hline \hline & \multicolumn{2}{c}{ Levels } \\
\cline { 2 - 3 } Medium Composition & $\mathbf{- 1}$ & $\mathbf{1}$ \\
\hline \hline DEPS-I $(\%)$ & 2 & 4 \\
DEPS-II $(\%)$ & 2 & 4 \\
$\left(\mathrm{NH}_{4}\right)_{2} \mathrm{SO}_{4}(\mathrm{~g} / \mathrm{L})$ & 1.5 & 3 \\
Yeast Extract $(\mathrm{g} / \mathrm{L})$ & 0.5 & 1 \\
$\mathrm{Na}_{2} \mathrm{HPO}_{4}(\mathrm{~g} / \mathrm{L})$ & 2 & 4 \\
$\mathrm{KH}_{2} \mathrm{PO}_{4}(\mathrm{~g} / \mathrm{L})$ & 1 & 2 \\
Inoculum conc. $(\%)$ & 1 & 2 \\
$\left.\mathrm{Temperature}^{\circ} \mathrm{C}\right)$ & 28 & 37 \\
$\mathrm{RPM}_{\text {Incubation Period }}$ & 60 & 120 \\
\hline \hline
\end{tabular}

Table 2 Effect of different environmental conditions on PHB production from Bacillus megaterium SW1-2 during growth on date palm syrup or DEPS

\begin{tabular}{|c|c|c|c|c|c|c|c|c|c|c|c|}
\hline $\begin{array}{l}\text { Exp. } \\
\text { No. }\end{array}$ & $\begin{array}{c}\text { DEPS-I } \\
(\%)\end{array}$ & $\begin{array}{c}\text { DEPS-II } \\
(\%)\end{array}$ & $\begin{array}{c}\left(\mathrm{NH}_{4}\right)_{2} \mathrm{SO}_{4} \\
(\mathrm{~g} / \mathrm{L})\end{array}$ & $\begin{array}{c}\text { Yeast } \\
\text { Extract } \\
\text { (g/L) }\end{array}$ & $\begin{array}{c}\mathrm{Na}_{2} \mathrm{HPO}_{4} \\
(\mathrm{~g} / \mathrm{L})\end{array}$ & $\begin{array}{c}\mathrm{KH}_{2} \mathrm{PO}_{4} \\
(\mathrm{~g} / \mathrm{L})\end{array}$ & $\begin{array}{c}\text { Inoculum } \\
(\%)\end{array}$ & $\begin{array}{c}\text { Temperature } \\
\left({ }^{\circ} \mathrm{C}\right)\end{array}$ & RPM & $\begin{array}{l}\text { Incubation } \\
\text { Period (h) }\end{array}$ & $\begin{array}{c}\text { PHB } \\
(\% \text { CDW })\end{array}$ \\
\hline 1 & 4 & 4 & 3 & 0.5 & 4 & 2 & 1 & 37 & 60 & 48 & 46 \\
\hline 2 & 4 & 2 & 3 & 1 & 2 & 2 & 1 & 28 & 60 & 72 & 9.8 \\
\hline 3 & 1.5 & 1.5 & 2.5 & 0.5 & 3.5 & 1.5 & 1.5 & 37 & 120 & 48 & 31 \\
\hline 5 & 4 & 4 & 1.5 & 1 & 2 & 1 & 1 & 37 & 120 & 72 & 11.5 \\
\hline 6 & 2 & 2 & 1.5 & 1 & 4 & 2 & 1 & 37 & 120 & 48 & 7.1 \\
\hline 7 & 2 & 2 & 3 & 1 & 4 & 1 & 2 & 37 & 60 & 72 & 32.7 \\
\hline 8 & 2 & 4 & 3 & 1 & 2 & 2 & 2 & 28 & 120 & 48 & 53.6 \\
\hline 9 & 2 & 4 & 3 & 0.5 & 4 & 1 & 1 & 28 & 120 & 72 & 10.6 \\
\hline 10 & 4 & 2 & 1.5 & 0.5 & 4 & 2 & 2 & 28 & 120 & 72 & 21.3 \\
\hline 12 & 2 & 2 & 1.5 & 0.5 & 2 & 1 & 1 & 28 & 60 & 48 & 23.8 \\
\hline 13 & 1.5 & 1.5 & 2.5 & 0.5 & 3.5 & 1.5 & 1.5 & 37 & 120 & 48 & 28.6 \\
\hline 14 & 2 & 4 & 1.5 & 0.5 & 2 & 2 & 2 & 28 & 60 & 72 & 46.1 \\
\hline
\end{tabular}




\section{Statistical analysis of the data}

Data of the PHB production were subjected to multiple linear regressions using MICROSOFT EXCEL 97 to estimate t-value, P-value and confidence level. The significance level ( $P$-value) was determined using the Student's t-test. Factors having highest t-value and confidence level over $95 \%$ were considered to be highly significant on PHB production. Data presented in this study measured in duplicate.

\section{RESULTS AND DISCUSSION}

Growth of Bacillus megaterium SW1-2 on date syrup (DEPS)

Among a group of polyhydroxybutyrate-producing bacilli explored for potential production of PHB biopolymer from an agro-industrial waste namely; date palm syrup (DEPS), Bacillus megaterium SW1-2 showed potent growth on DEPS or date syrup as a sole source of carbon. Elemental analysis revealed that $70 \%$ of the polymer accumulated during growth on date syrup or DEPS was carbon (data not shown).

\section{PHB accumulation by Bacillus megaterium SW1-2 cultivated on DEPS-I}

For economic visibility of PHB biopolymer production by $B$. megaterium SW1-2 date syrup or DEPS was used as a natural carbon source. Monitoring of PHB accumulation in presence of different DEPS concentrations was carried out. Data shown in Figure 1 indicated that the agro-industrial date palm syrup or DEPS can be used as a suitable renewable carbon source during PHB production. Maximum PHB production was recorded at the end of $\log$ phase and approximately $1.65 \mathrm{~g} / \mathrm{L}$ of PHB was accumulated after $48 \mathrm{~h}$ during cultivation on modified E2 medium supplemented with $2 \mathrm{~g} / \mathrm{L}$ of DEPS-I or date syrup. Furthermore, lower concentration of DEPS-I enhanced PHB accumulation (average of $42 \%$ CDW as well as $52.65 \%$ CDW of PHB accumulated after 24 and $48 \mathrm{~h}$ at concentration of 2 and 2.5 (w/v) of DEPS-I, respectively). Omar $\boldsymbol{e t}$ al. (2001) successfully used date palm syrup or DEPS as carbon source during PHB production. Page (1992) reported that the polymer production greatly enhanced in presence of unrefined sugars as well as complex nitrogen sources. It is assumed that various sugars namely; sucrose, glucose and fructose in date syrup or DEPs can be used as a carbon source by the $B$. megaterium SW1-2 cells during PHB production and may contribute to enhanced production. As previously recorded, glucose or sucrose can be used as carbon source during biopolymer production by many bacteria (Zhang et al., 1994, Valappil et al., 2007; Adwitiya et al., 2009; Reddy et al., 2009, Wang, 2011, Belal, 2013), supporting this conclusion.

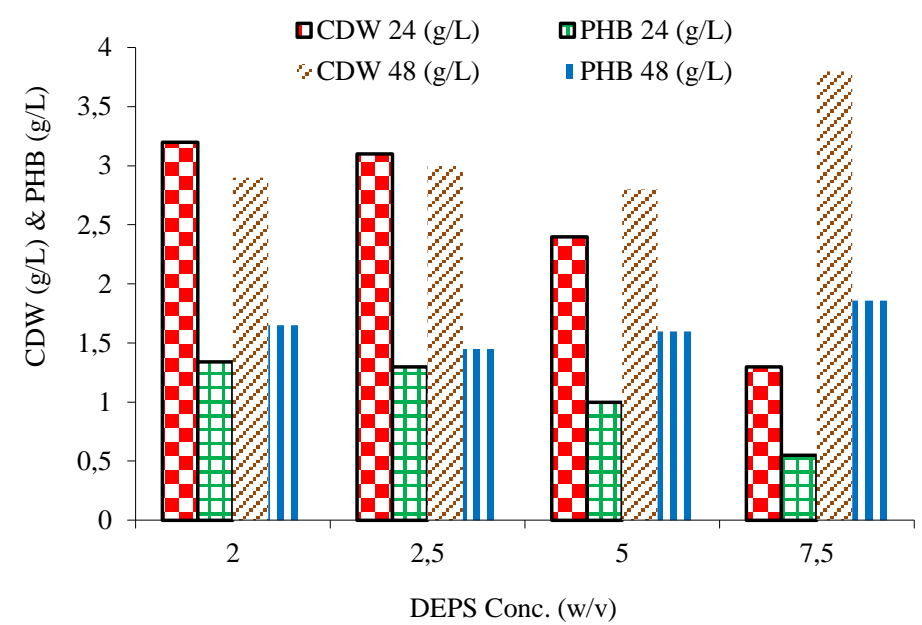

Figure 1 Effect of different date palm syrup or DEPS on growth and PHB production by $B$. megaterium $\mathrm{SW} 1-2$.

\section{PHB accumulation by Bacillus megaterium SW1-2 cultivated on Molasses}

In a trial to use other low-cost substrates for PHB production, B. megaterium SW1-2 allowed to grow on sugar cane molasses. Results revealed that $B$ megaterium SW1-2 showed clear growth and PHB accumulation during cultivation on modified E2 medium supplemented with sugar cane molasses as a sole carbon source (Figure 2). It revealed that $5 \mathrm{~g} / \mathrm{L}$ of sugar cane molasses was the optimal concnetration for PHB production by $B$. megaterium cells Approximately, 29.24\% and 26.1\% CDW of PHB accumulated after 24 and $48 \mathrm{~h}$, respectively. Lower concentrations of molasses resulted in approximately $50 \%$ reduction in $\mathrm{PHB}$, while clearly enhanced cell biomass. In concordance with our results, Beaulieu et al. (1995) used cane molasses together with ammonium salt for growth of Alcaligenes eutrophaus and PHB production. Recombinan Escherichia coli strain (HMS174/pTZ18u-PHB) capable of PHB production was reported by Liu et al. (1998). Belal (2013) successfully used simple carbon sources as well as molasses as a source of carbon for PHB production. It is assumed that higher concentrations of sugars in cane molasses namely; sucrose and fructose contribute to enhanced production of PHB in B. megaterium SW1-2.
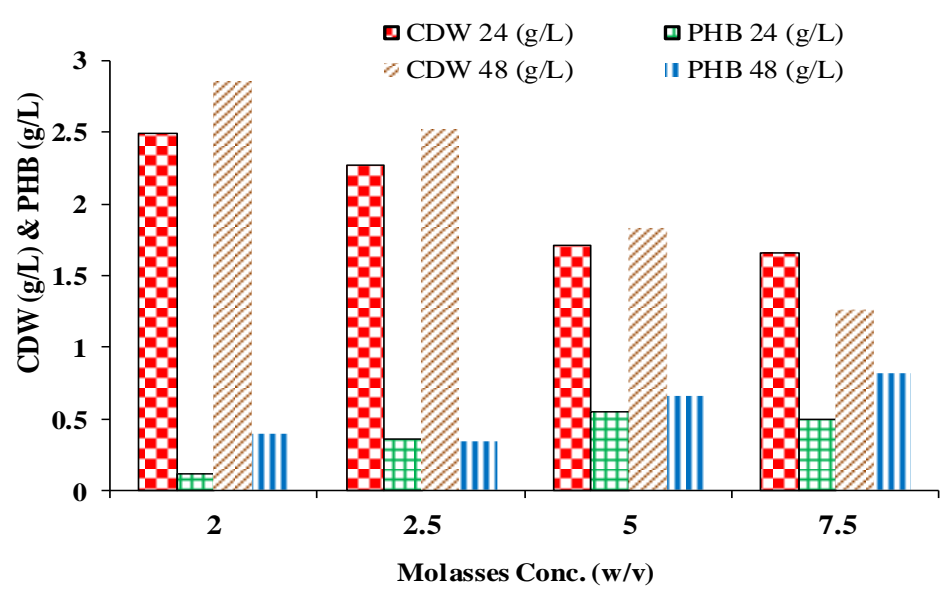

Figure 2 Effect of different sugar cane molasses on growth and PHB production by $B$. megaterium SW1-2.

\section{FT-IR spectroscopy analysis}

FT-IR Spectroscopic analysis of the polymer extracted from B. megaterium cells grown on modified E2 medium with date syrup or DEPS-I as a sole carbon source revealed a clear $\mathrm{C}-\mathrm{H}$ and carbonyl stretching bands highly characteristic to PHB. Two absorption bands occurring at 2921.36 and $2859.92 \mathrm{~cm}^{-1}$ indicated the presence of aliphatic group $-\mathrm{CH}_{3}$ and $-\mathrm{CH}_{2}$. The two other absorption bands at 1718.26 and $1267 \mathrm{~cm}^{-1}$ in the $\mathrm{PHB}$ sample conforming the presence of $\mathrm{C}=\mathrm{O}$ and $\mathrm{C}-\mathrm{O}$ stretching groups and were identical to PHB from some bacilli (Hong et al., 1999, Pandian et al., 2010; Valappil et al., 2007).

\section{$H^{1} \mathrm{NMR}$ and $\mathrm{C}^{13} \mathrm{NMR}$ spectroscopy}

Furthermore, analysis of extracted polymer by $\mathrm{H}^{1} \mathrm{NMR}$ revealed three groups of distinctive signals of the PHB polymer. A doublet at 1.22 and $1.25 \mathrm{ppm}$ represent methyl group $\left(-\mathrm{CH}_{3}\right)$ coupled to one proton and $2.28 \mathrm{ppm}$ resulted from methylene group $\left(-\mathrm{CH}_{2}\right)$ adjacent to an asymmetric carbon atom. The third signal was at $5.2 \mathrm{ppm}$ attributed to a methyne group $(-\mathrm{CH})$. Furthermore, $\mathrm{C}^{13} \mathrm{NMR}$ analysis was used to determine the structure of the isolated polymer from $B$ megaterium SW1-2 grown on the modified E2 medium. Four narrow lines appeared which were identical to the $\mathrm{C}^{13} \mathrm{NMR}$ spectra of PHB (Doi and Abe, 1990). The four peaks assigned for methyl $\left(\mathrm{CH}_{3} ; 21.2 \mathrm{ppm}\right)$, methylene $\left(\mathrm{CH}_{2}\right.$ $42.7 \mathrm{ppm})$, methine $(\mathrm{CH} ; 68.5 \mathrm{ppm})$ and carbonyl $(\mathrm{C}=\mathrm{O} ; 169.7 \mathrm{ppm})$ carbon resonance of PHB (Doi and Abe, 1990). Analysis collectively confirmed the molecular composition of the polymer to be PHB.

\section{Fed-batch cultivation and application of different pulsed feeding strategies}

Since PHB is a carbon-based biopolymer, it depends mainly on the nature and concentration of carbon source during synthesis and accumulation. Unfortunately, longer incubation period during batch cultivation leads to nutrient limitations especially for $\mathrm{C}$-source, hence fed-batch cultivation may provide promising solution. In this study commercial date syrup or DEPS-I was added in two pulsed feeding experiment. Results presented in figure 3 indicated that fedbatch cultivation can be used as successful strategy to optimize PHB production by Bacillus megaterium SW1-2 especially when using 48 h (runs 6 and 4) and 84 h (runs 2 and 4) pulsed feeding process. Modified E2 medium was preferred for PHB accumulation, recording total amount of 10.11 and $11.34 \%$ CDW of PHB for run 1 and 2 after $96 \mathrm{~h}$ cultivation, respectively. On the other hand, the lowest amount of PHB accumulated, $8.93 \%$ and $9 \%$ CDW of PHB during use of complex nutrient broth medium and applying the two different pulsed feeding processes run 3 and run 4, respectively. Surprisingly, there was general trend of increase in PHB production after feeding process and the total amount of PHB after fed-batch cultivation for $96 \mathrm{~h}$ recorded 6.86-fold increase in comparison to batch cultivation. Albuquerque et al. (2007) developed several strategies for polyhydroxyalkanoate (PHA) production from sugar cane molasses. They reported that beet molasses successfully replaced glucose as sole carbon source to produce poly-b-hydroxybutyrate by a recombinant Escherichia coli strain (HMS174/pTZ18u-PHB). Also, the positive impact of fed-batch cultivation on PHB production was reported by Hameih et al., (2013). 


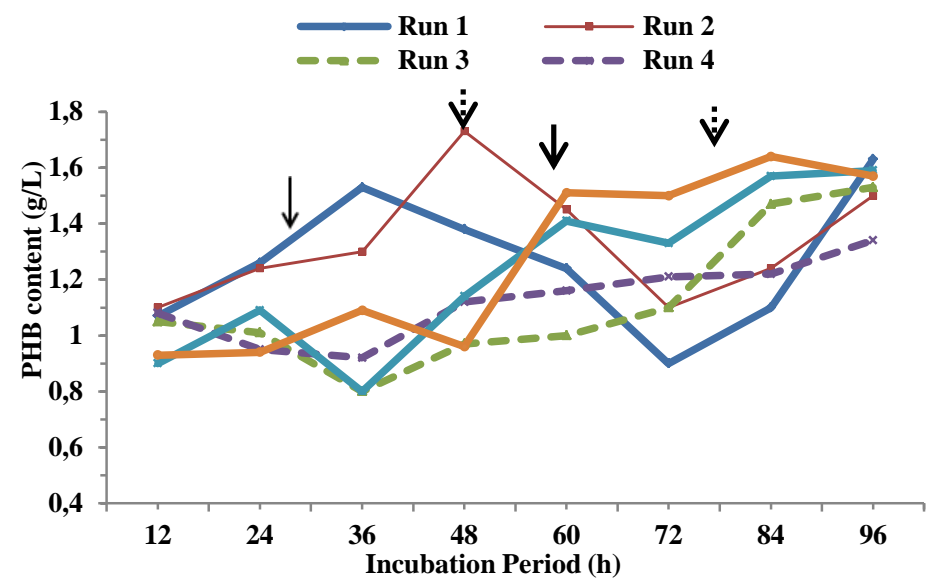

Legend:

- $\quad$ Runs $1,3,5=$ Feeding after 24 and 60 h \& Runs 2,4,6= Feeding after 48 and $84 \mathrm{~h}$

- $\quad$ Runs $1,2=$ MSM \& Runs 3,4 = NB (conc.=50\%) \& Runs $5,6=\mathrm{MSM}+\mathrm{NB}(50 \% \mathrm{NB}+50 \% \mathrm{MSM})$

- $\quad$ Arrows, pulsed feeding: straight $=24$ and $60 \mathrm{~h} \&$ dashed $=$ 48 and $84 \mathrm{~h}$

Figure 3 Strategies for fed-batch cultivation and PHB production by $B$. megaterium SW1-2 using two pulsed feeding processes.

\section{Evaluation of factors affecting PHB production}

Optimization of PHB production by application of Plackett-Burman design

For optimization studies a series of 14 experiments, with two central points (3 and 13) having the same concentrations used in basal medium, were carried out to screen for the most significant variables affecting PHB production. As presented in Table 1, ten crucial variables; covering biochemical and cultivation parameters were prescribed into 2 levels, coded -1 , and +1 . The design of the optimization experiment is given in Table 2 together with the experimenta results $(\% \mathrm{CDW})$. Regression analysis was performed to fit the response function (PHB production) with the experimental data. Analysis of variance indicated that PHB production can be well described by a polynomial model with a relatively high coefficient of determination $\left(R^{2}=0.93\right)$

$\mathrm{Y}_{\% \text { yield }}=27.99-1.29 \mathrm{X}_{1}+7.34 \mathrm{X}_{2}+2.33 \mathrm{X}_{3}-1.51 \mathrm{X}_{4}-1.01 \mathrm{X}_{5}+2.96 \mathrm{X}_{6}$ $+9.56 X_{7}+0.77 X_{8}-5.78 X_{9}-5.69 X_{10}$

One of the advantages of the Plackett-Burman design is to rank the effect of different variables on the measured response independent on its nature (either nutritional or physical factor) or sign (contributes positively or negatively) as in (Figure 4A). Ranking of factor estimates in a Pareto chart (Figure 4B) benefits in displays the magnitude of each factor estimate and is a convenient way to view the results of Plackett-Burman design (Strobel and Sullivan, 1999). It can be seen that, among those variables DEPS-II and inoculum concentration followed by $\mathrm{KH}_{2} \mathrm{PO}_{4}$ and $\left(\mathrm{NH}_{4}\right)_{2} \mathrm{SO}_{4}$ found to be the most significant variables that encourage PHB production. Interestingly, Beaulieu et al. (1995) reported that the best growth and PHB production were obtained with ammonium sulfate and sugar cane molasses as the growth activator. Indeed, DEPS-II or date syrup-II (Fresh syrup) is more significant than DEPS-I (commercial syrup) as indicated by the lower $p$-value (0.05) (Table 3 ).

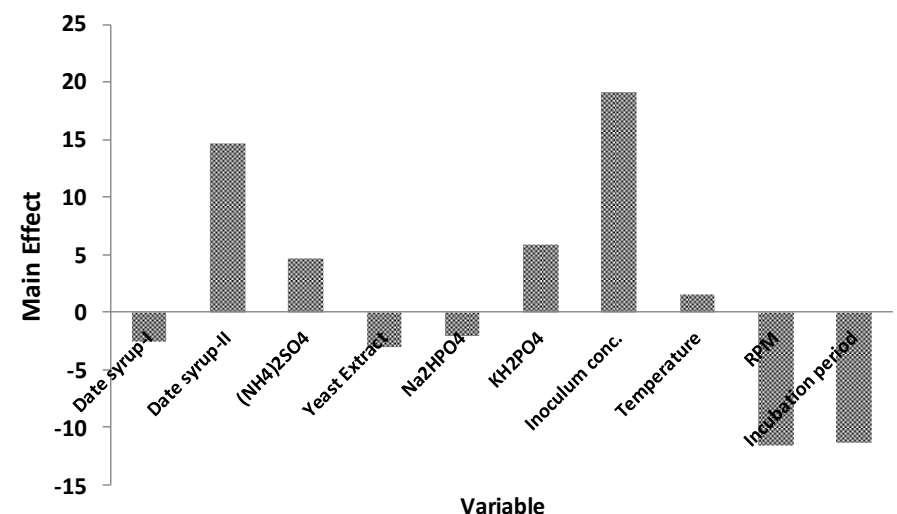

Figure 4A Effect of different environmental conditions on PHB production from Bacillus megaterium SW1-2.

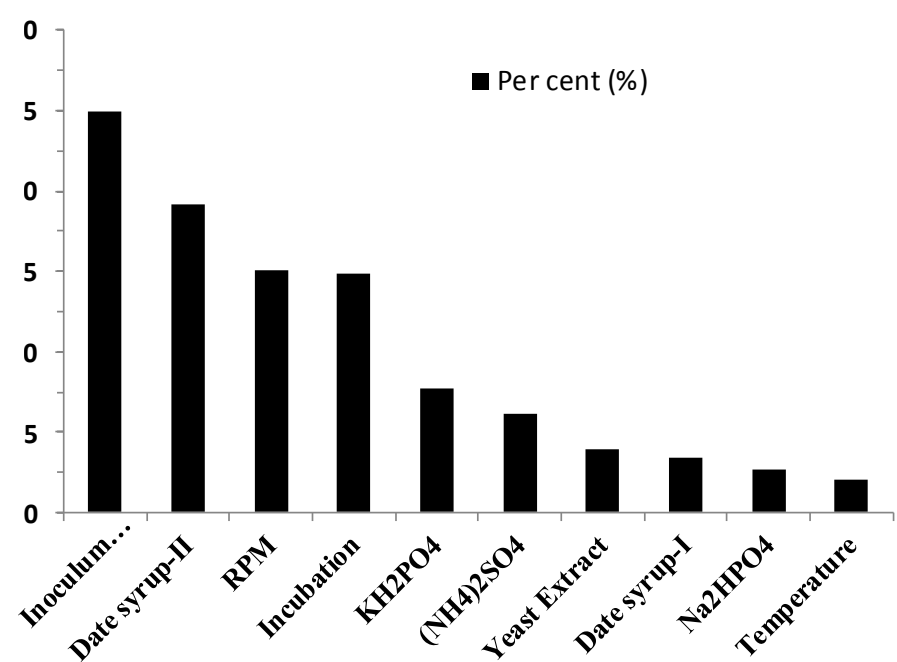

Figure 4B Pareto plot for Plackett-Burman parameter estimates of PHB production by Bacillus megaterium SW1-2.

Table 3 Statistical analysis of Plackett-Burman design showing coefficient values, $t$ - and P-values for each variable.

\begin{tabular}{lccc}
\hline Variable & Coefficient & t Stat & $\boldsymbol{P}$-value \\
\hline \hline Date syrup-I & -1.29 & -0.57 & 0.61 \\
Date syrup-II & 7.34 & 3.26 & 0.05 \\
$\left(\mathrm{NH}_{4}\right)_{2} \mathrm{SO}_{4}$ & 2.33 & 1.03 & 0.38 \\
Yeast Extract & -1.51 & -0.67 & 0.55 \\
$\mathrm{Na}_{2} \mathrm{HPO}_{4}$ & -1.01 & -0.45 & 0.68 \\
$\mathrm{KH}_{2} \mathrm{PO}_{4}$ & 2.96 & 1.31 & 0.28 \\
Inoculum conc. & 9.56 & 4.24 & 0.02 \\
Temperature $_{2}$ & 0.77 & 0.34 & 0.75 \\
$\mathrm{RPM}^{\text {Incubation period }}$ & -5.78 & -2.56 & 0.08 \\
\hline \hline
\end{tabular}

Interestingly, cane molasses contains many trace elements and vitamins such as thiamine, riboflavin, pyridoxine, and niacinamide (Crueger and Crueger, 1984) thus can be used as growth activators and help in enhancement of PHB production (Beaulieu et al., 1995). On the other hand, agitation (RPM) and incubation period have highly negative effect on PHB production. While, other factors namely; DEPS-I, yeast extract and $\mathrm{Na}_{2} \mathrm{HPO}_{4}$ still showed negative effect. Interestingly, the presence of growth activators in fresh DEPS-II as well as the absence of any preservative materials may explain its positive effect in comparison with the commercial DEPS-I. Furthermore, higher content of growth activators in fresh date syrup or DEPS-II makes it suitable substitutes for yeast extract that showed negative effect.

Results revealed that PHB production yield by B. megaterium SW1-2 was $53.6 \%$ CDW when cultivated on optimized medium developed by Plackett-Burman. Therefore, the statistical experimental design proved to be a powerful and useful tool for enhancing PHB production and confirm the necessity of the optimization process. In concordance with the obtained results in this work, enhanced PHB production by Lactobacillus acidophilus using statistical experimental design was reported by Hamieh et al., (2013). Interestingly, results reported in this study represent the first investigation on optimization of PHB production by application of statistical experimental design using date syrup or DEPS.

\section{CONCLUSION}

One of the most crucial variables affecting PHB production-economy is the nature of carbon source. B. megaterium SW1-2 stain exhibited nutritional versality in terms of varied growth and PHB accumulation during cultivatrion on different concentrations of the carbon-based agro-industrial wasts namely; date palm syrup (DEPS) or sugar cane molasses. PHB was successfully synthesized and intracellular accumulated in B. megaterium SW1-2 in presence of any of the used agro-industrial wastes as proven by FT-IR and NMR spectroscopy. Application of six different fed-batch cultivation strategies provides promising solution for nutritional limitation problems and clearly showed improved PHB production. Fed-batch cultivation recorded 6.87-fold increase in total amount of PHB produced after $96 \mathrm{~h}$ as compared with the amount produced under batch 
cultivation. Experimental design namely; Plackett-Burman proved to be a powerful and useful tool for enhancing PHB production $(53.6 \% \mathrm{CDW})$. The use of cheaper carbon sources such as date syrup (DEPS) or sugar cane molasses rather than glucose or sucrose greatly lower process economy and increase promises for biotechnological production of PHB biopolymer on industrial scale.

Acknowledgement: Authors are grateful for the financial support of this work by the Deanship of Scientific Research, Dammam University (Grant Application No-2012052)

\section{REFERENCES}

ADWITIYA, P., PRABHU, A., KUMAR, A., RAJAGOPAL, B., DADHE, K., PONNAMMA, V., SHIVAKUMAR, S. 2009. Optimization of process parameters for maximum poly-Beta-hydroxybutyrate (PHB) production by Bacillus thuringiensis IAM 12077. Polish Journal of Microbiology, 58, 149-154. ALBUQUERQUE, M. G. E., EIROA, M., TORRES, C., NUNES, B. R., REIS, M. A. M. 2007. Strategies for the development of a side stream process for polyhydroxyalkanoate (PHA) production from sugar cane molasses. Journal of Biotechnology, 130, 411-421. http://dx.doi.org/10.1016/j.jbiotec.2007.05.011

ANDERSON, A. J., DAWES, E. A. 1990. Occurrence, metabolism, metabolic role, and industrial uses of bacterial polyhydroxyalkanoates. Microbiological Review, 54, 450-472.

BEAUliEU, M., BEAULIEU, Y., MELINARD, Y., PANDIAN, S., GOULET, J. 1995. Influence of Ammonium Salts and Cane Molasses on Growth of Alcaligenes eutrophus and Production of Polyhydroxybutyrate. Applied and Environmental Microbiology, 61, 165- 169. http://aem.asm.org/content/61/1/165

BELAL, E. B. 2013. Production of Poly- $\beta$-Hydroxybutyric Acid (PHB) by Rhizobium elti and Pseudomonas stutzeri. Current Research Journal of Biological Sciences, 5, 273-284.

BELMA, A.Y., ZEHRA, N., YAVUZ, B. 2002. Determination of PHB growth quantities of certain Bacillus sp. isolated from soil. Turkish Electronic Journal of Biotechnology, Special issue: 24-30.

BEREKAA, M. M. 2012. Genotypic Detection of Polyhydroxyalkanoateproducing Bacilli and Characterization of phaC Synthase of Bacillus sp. SW1-2. Life Science Journal, 9, 518-527.

BEREKAA, M. M., AL THAWADI, A. M. 2012. Biosynthesis of Polyhydroxybutyrate (PHB) biopolymer by Bacillus megaterium SW1-2: application of Box-Behnken design for optimization of process parameters. African Journal of Microbiology Research, 6, 838-845. BHUWAL, A. K. SINGH, G., AGGARWAL, N. K., GOYAL, V., YADAV, A. 2013. Isolation and screening of polyhydroxyalkanoates producing bacteria from pulp, paper, and cardboard industry wastes. International Journal of Biomaterials, ID 752821, 1 10. http://dx.doi.org/10.1155/2013/752821

BUCCI, D. Z., TAVARES, L. B. B., SELL, I. 2005. PHB packaging for storage of food products. Polymer Testing, 24, 564-571. http://dx.doi.org/10.1016/j.polymertesting.2005.02.008

CHEN, G. O., WU, Q. 2005. The application of polyhydroxyalkanoates as tissue engineering materials. Biomaterials, 26, 6556-6578 http://dx.doi.org/10.1016/j.biomaterials.2005.04.036

CRUEGER, W., CRUEGER. A. 1984. Biotechnology: a textbook of industria microbiology. Sinauer Associates Inc., Science Tech, Inc., Madison, Wis. ISBN:0878931260 9780878931262

DOI, Y. AND ABE, C. 1990. Biosynthesis and characterization of a new bacterial copolyester of 3-hydroxyalkanoates and 3-hydroxy- $\omega$ - chloroalkanoates Macromolecules, 23, 3705-3707.

DU, G., YU, J., 2002. Metabolic analysis on fatty acid utilization by Pseudomonas oleovorans: mcl-poly-3-hydroxyalkanoates) synthesis versus oxidation. Process Biochemistry, 38, 325-332. http://dx.doi.org/10.1016/S0032 9592(02)00084-5

GOUDA, M. K., SWELLAM, E. A., OMAR, H. S. 2001. Production of PHB by a Bacillus megaterium strain using sugarcane molasses and corn steep liquor as sole carbon and nitrogen sources. Microbiology Research, 156, 201-207. http://dx.doi.org/10.1078/0944-5013-00104

HALAMI, P. M. 2008. Production of polyhydroxyalkanoate from starch by the native isolate Bacillus cereus CFR06. World Journal of Microbiology and Biotechnology, 24, 805-812. http://ir.cftri.com/id/eprint/10165

HAMIEH, A., OLAMA, Z., HOLAIL, H. 2013. Microbial production of polyhydroxybutyrate, a biodegradable plastic using agro-industrial waste products. Global Advanced Research Journal of Microbiology, 2(3), 054-064.

HONG, K., SUN, S., TIAN, W., CHEN, G. Q., HUANG, W. 1999. A rapid method for detecting bacterial polyhyroxyalkanoates in intact cells by Fourie transform infrared spectroscopy. Applied Microbiology and Biotechnology, 51, 523-526. http://dx.doi.org/10.1007/s002530051427

ISHIZAKI, A., TANAKA, K., TAGA, N. 2001. Microbial production of poly-3hydroxybutyrate from $\mathrm{CO}_{2}$. Applied Microbiology and Biotechnology, 57, 6-12. http://dx.doi.org/10.1007/s002530100775

KHANAFARI, A., SEPAHEI, A. A., MOGHARAB, M. 2006. Production and recovery of poly- $\beta$-hydroxybutyrate from whey degradation by Azotobacter
Iranian Journal for Environmental Health and Science Engineering, 3, 193-198 http://ijehse.tums.ac.ir/index.php/ijehse/article/view/89

KHANNA, S., STRIVASTAVA, A. K. 2005. Statistical media optimization studies for growth and PHB production by Ralstonia eutropha. Process Biochemistry, 40, 2173-2182. http://dx.doi.org/10.1016/i.procbio.2004.08.011

KIM, B. S., 2000. Production of poly(3-hydroxybutyrate) from inexpensive substrates. Enzyme and Microbial Technology, 27, 774-777. http://dx.doi.org/10.1016/S0141-0229(00)00299-4

KIM, P., KIM, J. H., OH, D. K. 2003. Improvement in cell yield of Methylobacterium sp. reducing the inhibition of medium components for poly-bhydroxybutyrate production. World Journal of Microbiology and Biotechnology, 19, 357-361. http://dx.doi.org/10.1023/A:1023969629568

LAW, K. H., LEUNG, Y. C., LAWFORD, H., CHAU, H., LO, W. H., YU, P. H. 2001. Production of polyhydroxybutyrate by Bacillus species isolated from municipal activated sludge. Applied Biochemistry and Biotechnology, 91, 515524. http://dx.doi.org/10.1385/ABAB:91-93:1-9:515

LEE, S. Y., MIDDELBERG, A. P. J., LEE, Y. K. 1997. Poly (3 hydroxybutyrate) production from whey using recombinant Escherichia coli. Biotechnology Letters, 19, 1033 http://dx.doi.org/10.1023/A:1018411820580

LIU, F., LI, W., RIDGWAY, D., GU T. 1998. Production of poly-bhydroxybutyrate on molasses by recombinant Escherichia coli. Biotechnology Letters, 20, 345-348. http://dx.doi.org/10.1023/A:1005367011378

LUENGO, M. J., GARCIA, B., SANDOVAL, A., NAHARRO, G., OLIVERA R. E. 2003. Bioplastics from microorganisms. Current Opinion in Microbiology, 6, 251-260. http://dx.doi.org/10.1016/S1369-5274(03)00040-7

MADISON, L. L., HUISMAN, G. W. 1999. Metabolic engineering of poly(3ydroxyalcanoates): From DNA to plastic. Microbiology and Molecular Biology Reviews, 63, 21-53. http://mmbr.asm.org/content/63/1/21\#ref-list-1

MOKHTARI-HOSSEINI, Z. A., VASHEGHANI-FARAHANI, E. HEIDARZADEH-VAZIFEKHORAN, A., SHOJAOSADATI, S. A. KARIMZADEH, R., DARANI, K. K. 2009. Statistical media optimization for growth and PHB production from methanol by a methylotrophic bacterium. Bioresource Technology, 100, 2436-2443. http://dx.doi.org/10.1016/j.biortech.2008.11.024

NATH, A., DIXIT, M., BANDIYA, A., CHAVDA, S., DESAI, A. J. 2008 Enhanced PHB production and scale up studies using cheese whey in fed batch culture of Methylobacterium sp. ZP24. Bioresoure Technology, 99, 5749-5755. http://dx.doi.org/10.1016/j.biortech.2007.10.017

NIKEL, P. I., PETTINARI, M. J., MENDEZ, B. S., GALVAGNO, M. A. 2005. Statistical optimization of a culture medium for biomass and poly(3 hydroxybutyrate) production by a recombinant Escherichia coli strain using agroindustrial by-products. International Microbiology, 8, 243-250.

OJUMU, T. V., YU, J., SOLOMON, B. O. 2004. Production of Polyhydroxyalkanoates, a bacterial biodegradable polymer. African Journal of Biotechnology, 3, 18-24.

OMAR, S., RAYES, A., EQAAB, A., VOß, I., STEINBÜCHEL, A. 2001. Optimization of cell growth and poly(3-hydroxybutyrate) accumulation on date syrup by a Bacillus megaterium strain Biotechnology Letters, 23, 1119-1123. http://dx.doi.org/10.1023/A:1010559800535

PANDIAN, R. S., DEEPAK, V., KALISHWARALAL, K., RAMESHKUMAR, N., JEYARAJ, M., GURUNATHAN, S. 2010. Optimization and fed-batch production of PHB utilizing dairy waste and sea water as nutrient sources by Bacillus megaterium SRKP-3. Bioresource Technology, 101, 705-711. http://dx.doi.org/10.1016/j.biortech.2009.08.040

PLACKETT, R. L., BURMAN, J. P. 1946. The design of optimum multifactorial experiments. Biometrika, 33, 305-325. http://dx.doi.org/10.1093/biomet/33.4.305 RAWTE, T., MAVINKURVE, S. 2002. A rapid hypochlorite method for the extraction of polyhydroxyalkonates from bacterial cells. Indian Journal of Experimental Biology, 40, 924-929.

REDDY, V. S. T., MAHMOOD, K. S. 2009. Production of PHB and P(3HB-co$3 \mathrm{HV})$ biopolymers of Bacillus megaterium strain OU303A isolated from municipal sewage sludge. World Journal of Microbiology and Biotechnology, 25, 391-397. http://dx.doi.org/10.1007/s11274-008-9903-3

SANTIMANO, M. C., PRABHU, N. N., GARG, S. 2009. PHB production using low-cost Agro-industrial wastes by Bacillus sp. strain COL1/A6. Research Journal of Microbiology, 4, 89-96. http://dx.doi.org/10.3923/jm.2009.89.96

SHARMA, L., SINGH, A. K., PANDA, B., MALLICK, N. 2007. Process optimization for poly-hydroxybutyrate production in a nitrogen fixing cyanobacterium, Nostoc muscorum using response surface methodology. Bioresource http://dx.doi.org/10.1016/j.biortech.2006.04.016 98 987-993.

SINGH, G., KUMARI, A., MITTAL, A., YADAV, A., AGGARWAL, N. K. 2013. Poly $\beta$-Hydroxybutyrate Production by Bacillus subtilis NG220 Using Sugar Industry Waste Water. BioMed Research International, Article ID 952641. http://dx.doi.org/10.1155/2013/952641

STEINBÜCHEL, A. 2001. Perspectives for Biotechnological Production and Utilization of Biopolymers: Metabolic Engineering of Polyhydroxyalkanoate Biosynthesis Pathways as a Successful Example. Macromolecular Bioscience, 1 , 
$1-24$.

http://dx.doi.org/10.1002/1616-5195(200101)1:1<1::AID

MABI1>3.0.CO;2-B

STROBEL, R. J., SULLIVAN, G. R. 1999. Experimental design for improvement of fermentations. In Manual of industrial Microbiology and Biotechnology, ed. by Demain, A. L., Davies, J. E., ASM Press, Washington, pp. 80-93. ISBN: 1555811280

TAJIMA, K., IGARI, T., NISHIMURA, D., NAKAMURA, M., SATOH, Y., MUNEKATA, M. 2003. Isolation and characterization of Bacillus sp. INT005 accumulating polyhydroxyalkanoate (PHA) from gas field soil. Journal of Bioscience and Bioengineering, 95, 77-81. http://dx.doi.org/10.1016/S13891723(03)80152-4

TAMER, I. M., M. MOO-YOUNG, CHISTI, Y. 1998. Disruption of Alcaligenes latus for recovery of poly(b-hydroxybutyric acid): Comparison of high pressure homogenization, bead milling, and chemically induced lysis. Industrial and Engineering Chemistry Research, 37, 1807-14. http://dx.doi.org/10.1021/ie9707432

URTUVIA, V., VILLEGAS, P., GONZÁLEZ, M., SEEGER, M. 2014. Bacterial production of the biodegradable plastics polyhydroxyalkanoates. Internationa journal of Biological macromolecules, 70, 208-13. http://dx.doi.org/10.1016/j.ijbiomac.2014.06.001

VAN DER WALLE, G. A., DE KONING, G. J., WEUSTHUIS, R. A., EGGINK G. 2001. Properties, modification, and application of biopolyesters. Advances in Biochemical Engineering and Biotechnology, 71, 263-291. http://dx.doi.org/10.1007/3-540-40021-4 9

VALAPPIL, P. S., MISRA, K. S., BOCCACCINI, R. A., KESHAVARZ, T. BUCKE, C., ROY, I. 2007. Large-scale production and efficient recovery of PHB with desirable material properties, from the newly characterized Bacillus cereus SPV. Journal of Biotechnology, 132, 251-258. http://dx.doi.org/10.1016/j.jbiotec.2007.03.013

WANG, B. 2011. Production of Polyhydroxybutyrate (PHB) by Alcaligenes latus using Sucrose based synthetic media and sugarbeet juice. Master of science, North Carolina State University. http://repository.lib.ncsu.edu/ir/bitstream/1840.16/7361/1/etd.pdf

WANG, F., LEE, S. Y. 1997. Production of Poly(3-Hydroxybutyrate) by FedBatch Culture of Filamentation-Suppressed Recombinant Escherichia coli. Applied and Environmental Microbiology, 63, 4765-4769. http://aem.asm.org/content/63/12/4765

WATANABE, T., SHINOZAKI, Y., SUZUKI, K., KOITABASHI, M. YOSHIDA, S., SAMESHIMA-YAMASHITA, Y., KITAMOTO, H. K. 2014 Production of a biodegradable plastic-degrading enzyme from cheese whey by the phyllosphere yeast Pseudozyma antarctica GB-4(1)W. Journal of Bioscience $\begin{array}{lll}\text { and Bioengineering, 183-187. } & \text { 118(2), }\end{array}$ http://dx.doi.org/10.1016/j.jbiosc.2014.01.007

ZHANG, H.,OBIAS, V., GONYER, K., DENNIS, D. 1994. Production of polyhydroxyalkanoates in sucrose-utilizing recombinant Escherichia coli and Klebsiella strains. Applied and Environmental Microbiology, 60, 1198-1205. http://aem.asm.org/content/60/4/1198

ZINN, M., WITHOLT, B., EGLI, T. 2001. Occurrence, synthesis and medical application of bacterial polyhydroxyalkanoate. Advanced Drug Delivery Reviews, $53,5-21$. 